\title{
Improvement of Mathematical Lateral Thinking Skills and Student Character through Challenge-Based Learning
}

\author{
Wati Susilawati, Iyon Maryono, Tutut Widiastuti \\ Mathematics Study Program \\ UIN Sunan Gunung Djati Bandung \\ Bandung, Indonesia \\ wati85@uinsgd.ac.id,iyonmaryono@uinsgd.ac.id, \\ widiastuti@uinsgd.ac.id
}

\author{
Ridha Abdullah \\ Journalism Communication Science \\ UIN Sunan Gunung Djati Bandung \\ Bandung, Indonesia \\ ridhazia@gmail.com
}

\begin{abstract}
- the challenge relevance of lateral thinking and mathematical character that indicate geometry eternal issue is the most controversial mathematics branch, the difficult incomprehension source unit, at all levels of education. This research aims to improve the students' ability of lateral thinking and mathematical characters through a challenged-based learning. This research is a Quasi-Experiment Non-equivalent Pretest-Posttest Control Group Design that involves 73 students of Mathematics Study at the Faculty of Tarbiyah and Teaching UIN Sunan Gunung Djati Bandung as the samples which is categorized into two classes, Class $B$ as the control class, and Class $\mathrm{C}$ as the experiment class. The findings show that: the improvement of the challenge-based learning of students' ability of mathematical lateral thinking is higher than the students that receive expository learning based on the students' mathematics entirety and initial knowledge. There is an interaction effect between the learning types and mathematics initial knowledge toward the students' lateral thinking. The challenge-based students' caharcters improvement is higher than those who receive expository learning. The challenge-based learning can facilitate conflict processes, invention processes, social interaction processes and the students' reflective processes so that the students' lateral thinking and characters are better than the expository learning.
\end{abstract}

Keywords-lateral thinking; character; challenge-based learning

\section{INTRODUCTION}

Life is surrounded and shaped from structures (geometry and surface), therefore a learning of geometry is very important to be studied by students of pre-service teacher education, it can be seen from the proportion of subjects of geometry, algebra, trigonometry, calculus and school math learning are almost $40 \%$ with the aim of developing the ability to think mathematically, reasoning, and develop spatial intuition about the real world. The purpose of learning geometry is that students will understand the concepts and procedures and are able to solve various problem tasks, they must use most of their time to solve the problem [1, 2]. However, the problem of geometry learning based on empirical evidence in the field of both in Indonesia and abroad show the results are still not satisfactory $[2,3]$. A preliminary study by Susilawati (2017) resulted that the low geometry of the students is due to the inability of (1) drawing up 3D space to 2D [2]. Similarly reverse that the difficulty of drawing from 2D to $3 \mathrm{D}$ are due to (2) the lack of creative ideas of spatial sense impact on the mistake of interpreting geometry (3) consider the image of space as a flat image so that the crossing line is considered to be intersected (4) construct a representation, two dimensions space into three dimensions seen from various angles without the support of learning media.

The mentioned problems can be addressed and minimized one of which is by the way of external factors through the development of teaching materials in accordance with the objectives, arrange student worksheets, classroom management, create a media project by students, as well as the student autonomy in their activities and the way students think based on the principles of seeing problems critically and be able to solve various problems from different point of view creatively, which grows adaptively through the ability of lateral thinking.

The ability of lateral thinking can be developed through challenging reasoning tasks in the process of learning math. It is very important of how the teacher can be provide rich opportunities to study that comes from student involvement in challenging tasks [4, 5]. High level reasoning mental of someone can decide the role of mathematical lateral thinking in the process of intellectual thinking, greatly affects on a success of individual in resolving real world problems. It is not uncommon using lateral thinking to build a mathematical truth. Even though the mathematical truth should be obtained by a verification built through logical-deductive means based on axiomatic, however it is often the case that a truth is obtained through lateral thinking ways; hence the truth can be 
accepted. In math, deductive thinking, creative thinking, intuitive and lateral thinking ways should be able to synergize to each other. Basically, every action taken by human is the result of principles of thinking, which is not only rely on natural and logical paths, but also relies on the paths beyond the linear thinking or often to be called as out of the box that is a "deviant" creative thinking also known as de Bono as "lateral thinking". [4, 6].

Lateral thinking is a process of solving problems by using imagination that emphasizes the demand of various problems solving different from ordinary ideas to get new ideas [6]. Providing opportunity and independence to think creatively with direction and guidance will realize the habit for lateral thinking skill. The ability of lateral thinking will sharpen the creative side in a person to overcome thing he is facing, lateral thinking is closely related to creativity [7]. Creativity is often only a description of a result, therefore lateral thinking described as a process. Mathematicians and researchers in mathematics and psychology education have studied the creativity of mathematics in various scientific points of view $[8,9]$; also associate creativity with the attitude of openness, imagination and courage in taking risks. A creative environment should include open activity and non-routine problem providing the independence to implement the imaginative ideas and find new methods or solutions with different perspectives [10].

According to Susilawati (2017), students are trained for lateral thinking; it means that they see a problem from different perspectives. Not being forced to accept a teacher's idea, they can think freely to obtain positive goals and direct them so they are able to solve problems not only one single answer in achieving the truth [4]. In lateral thinking, the priority is recognition of idea/how student can come up with an idea regardless of the result of judgment, and lateral thinking directs how student can perceive a problem from different perspective [11]. Indicator of Lateral Thinking in mathematics, modification including $[4,11]$ :

- Idea identification: recognize the dominant idea of a mathematical problem at hand. So as to know the mathematical concepts or strategies that can be used to solve mathematical problem.

- Openness: accept different concept of mathematics that can encourage ideas to solve problem at hand related to the concept of solution or not, so as to be able to consider any possibility before making a decision.

- Development: connect a concept/idea thus becoming some strategies may be right or wrong to find a new way in solving mathematical problems.

- Flexibility: an ability that can perceive a problem from different perspectives, finding many different alternatives of solution.

- Originality: the novelty refers to uniqueness of any given responds. Originality showed by an unordinary respond, unique, and rarely happened.
- Analyze the facts: an ability in investigating, examining the facts in a strategy so that the alternative used is reasonable in solving a problem.

The core of lateral thinking is the number of problems that need different perspectives in the process of finding solution to a problem in different ways than usual or in new ways. Generally, lateral thinking is triggered by challenging tasks. Students perspective of discipline can grow because of tasks or problems that they must work on, students cannot get deep understanding through repeation but learn by actively connecting and giving meaning to study by building past experiences through group tasks [12]. The lateral thinking ability in this study is manipulating geometry as one of the spatial ability. Through geometry manipulation, it can be developed of how to obtain mathematical truth. A person cannot correcty distinguish a relation between the elements of geometry without concrete media, student who studies without media and only relies on visualization, risk of having misconception. Development of lateral thinking ability can utilize various learning media as project tasks in a group assigned to the students such as, origami, geoboard, mekorama, pop up book, geogebra, to train the students using their motoric skill. This shows that lateral thinking lateral is a demand of thinking process that should be accommodated in math learning in class.

Beside the described cognitive aspect, every person who learns math need to develop affective aspect that is character. Character is basically inseparable part of daily live, character building of someone does not happen in a short time. It needs a long process until someone has strong character that builds the individual become agent of change for himself and the surrounding community. The character as personal nature that is relatively stable to a self of individual that became the basis of attitude appearance in high standar of value and norm [13, 14]. Character is as a collection of values and norms which is fixed on a system that underlies thinking, attitude and behavior that are shown. Character or nature is inner nature impacting the whole thinking, attitude, and character possessed by human which were formed from the result of internalization of policy that believed and used as to perceive, think, behave, talk, and act in daily life. Character building effectively involves three institutions that are family, school, and community. Family is as a place of affection; schools that build attitudes, character, personality, and society as a whole point of view of the value system [14].

The development of individual characters will not appear without realization in group life. Based on the considerations in this study were studied two characters of individual character and group character. Individual characters have four indicators that are meticulous, creative, resilient, and curiosity [14]. Meticulous in doing work carefully, full of consideration in thinking, behaving, and careful in keeping to act careless; creative as an ability to solve problem with new way, idea or new work; resilient is a personality which does not feel weak against something and face it, always keep the consistency of his persistence; curiousity showed by always asking, listening to others with empathy, creating, and innovate. 
On the other hand, indicator of group character has four indicators that are leadership, mutual respect, cooperates and carring attitude. Group character is the quality of collective attitudes which are unique, reflected in awareness, understanding, taste, thought, feeling, heart, and intention in group [14]. Leadership as a behavior designed to give benefit for the group; respect others as behaviors that do not exude pride; cooperation as group processes support each other to achieve consensus results; caring attitude as a behavior to help others who have difficulty. Mathematics learning should be integrated with the planting of values, which will shape the character of the student.

Therefore, improving the implementation of learning process becomes an interesting thing to be studied. Learning that can solve the problem is learning based on challenge triggering students to learn from tasks, materials, and projects of making learning media, and constructing a contextually stimulated divergent problem that triggers challenged students to explore the project in front of the class, even preparing a math profesional pre-serving teacher to not only rely on selfgenerated knowledge, the involvement of learner and other learners reconstruct concept of learning material to overcome conflicts, also practice to finish continous tasks is very demanded to fulfill the challenge of the problems. Quality of education system always changes according to the demand of community which involving development of student potential [15].

The implementation of challenge-based learning consists of three important parts: Problem-based learning, contextual learning and project-based learning. Challenge-based learning is viewed as a learning that is capable of implementing the demands of students to work hard using their power when faced with a problem situation that is contrary to their cognitive structure, there is a conflict that will ultimately result in a change of understanding and new knowledge for students [16, 17]. The syntax of learning based on the challenge of existence is $[17,18]$ :

- Idea or The Big Idea, some concepts of geometry that can be explored in many interesting ways; these ideas will become the main focus of the learning until it's done.

- Essential Questions, individual students' questions to help in disclosing the truths.

- The Challenge is the form of illstructure problem solving, does not rule out students posing a problem, a challenge that can illustrate the main idea or idea where students in other groups make more specific answers or find solutions in action.

- Guiding Questions or scaffolding, that question represents the knowledge required by students to correctly find the right challenge.

- Guiding Activities, in the form of probing or prominent even exploration, simulation, games, and other types of activities that help students answer the challenge as the basis for them to build innovative, insightful and realistic solutions.
- Guiding Resources, can be focused on the use of teaching materials, resource books, internet, videos that can support activities and assist students in building solutions.

- Solution, every solution must be realistic, can be done, can be interpreted clearly. The solution is the final answer to the challenge.

- Assessment, solution judged from its relation to challenge, content appropriateness, applicability, and efficacy of ideas and other general matters.

- Publishing, there are many opportunities to document the experience by presenting to others or publishing their results online.

Beside the emphirical reality that mentioned above, there is another factor that can contribute to lateral thinking ability that is basic mathematical knowledge (BMK) which is categorized into three level that are: clever, moderate, low by the variative consideration of the major in class with different background, in one class there are students come from High School/Aliyah major in Natural Social Science, Language, and Vocational High School. This leads to the mathematical knowledge that each student possesses. Technical BMK aims to determine the equality between experimental groups and control groups where each research sample has mathematical knowledge in the same initial conditions. In addition, PAM categorization is to know the difference of treatment in each category to students during the learning process.

Explicitely, the problems of this study are as follow:

- Is the improvement of lateral mathematical thinking ability among students who follow challenge-based learning is higher than the students whose expository learning is reviewed based on the whole student?

- Is the improvement of lateral mathematical thinking ability among students who follow challenge-based learning is higher than the students whose expository learning is reviewed based on Basic Mathematical Knowledge (BMK) of students in clever, moderate, or low level?

- Are there interactions between BMK types (challengebased and expository learning) and categories (clever, moderate, low) towards improving mathematical lateral thinking of students?

- Is the increase in student character who follow challenge-based learning higher than in expository learning students?

Research Purposes analyzing comprehensively:

- The improvement of lateral mathematical thinking ability among students who follow challenge-based learning and students who follow expository learning are reviewed from: a) whole students; b) based on student BMK in clever, moderate, low level.

- The influence of interaction between type of learning approach (based on challenge and expository) and 
BMK on lateral mathematical thinking ability of students.

- The improvement of students' character who follow challenge-based learning and expository learning.

This research provides the benefits of real and new experiences, on how to design and implement challenge-based learning with character implementation involving students actively, interactively, and productively in learning activities such as discussing, questioning, exploring, presupposing, expressing new ideas, investigating, analyzing, constructing an example, identifying the conformity of the solution. These can be a reference for researchers and practitioners of mathematics education such as lecturers, teachers, and pre-service teacher education students in developing the implementation of learning on other topics.

\section{RESEARCH METHODOLOGY}

Type of the research is an experiment on two homogenous groups. Sampling is randomly selected from level of moderate qualification of UIN SGD Bandung Mathematics Study, with 73 students of pre-service teacher education divided into two classes, 35 students class B as control class with classical expository learning, and 38 students class $\mathrm{C}$ as experiment class with cooperative challenge-based learning through pre and posttest control group design. Instruments used are test of basic mathematical knowledge (BMK) to students, pretest and posttest the ability of lateral mathematical thinking, and character questionnaires. Before the instrument is used, it is first validated by five mathematics education experts through content validation and face validation, then revised and tested; test results analyzed the validity, reliability, distinguishing and difficulty. To measure the validity of the content of the considerations based on the compatibility with the questions and the criteria of the BMK aspects, the compatibility with the subject matter, the compatibility with the students' difficulty level, and the compatibility with the lateral thinking ability indicator. Quantitative data is done through the difference test of Independent t-Test if distribution data is normal, and MannWithney U Test if data distribution is not normal, whereas to see interaction between dependent variables using $F$ Test, if it is fulfilled by normality test, and Adjusted Rank Transform Test if it is not fulfilled by its normality, two-way ANOVA. Qualitative data analysis is descriptive analysis.

\section{RESULTS AND DISCUSSION}

The arrangement of teaching material scenarios was developed based on a preliminary study of the learning barriers experienced by students as teachers and lecturers as learners. The results of the study reveal the obstacles experienced by students in epistemology, i.e. knowledge or concepts of geometry, construction and reasoning. Lateral thinking is one of three cognitive processes that fulfill a special epistemological function in geometry, in addition to construction and reasoning [4]. According to the result of observation, that the students does not recall in detail the three dimensional geometry formula, the concept that has been studied does not last long in their memory (long-term memory), although the students are required to propose problems according to their experience.

The experimental research began with the provision of basic mathematical knowledge (BMK) tests to both groups, with the purpose of identifying and distributing students at each clever, moderate and low level. This distribution indicates that the average basic mathematical knowledge of the students is included in the sufficient category. Then, pretest had been done, the test results statistically showed that the overall thinking ability of students of both groups before getting treatment, have the ability of lateral thinking on the material to be taught relatively no different, the pretest experimental group rate of 13.29 and the control group 13.57. The mean pretest score indicates that students' early ability of lateral thinking is categorized as low.

It was identified that the experimental group after the implementation of challenge-based learning, there was increasing on the mean of students' lateral mathematical thinking ability. On average, this difference is indicated from the average postes score obtained, the overall postes score of the students in the experimental group has a mean of 74.34 and the control group of 64.43. It was described that the mean postes score of lateral mathematical thinking ability of experimental group students either whole or in the category of BMK (clever, moderate, low) has a higher diversity than the control group students.

With these results, the difference in the improvement of lateral mathematical thinking ability in both groups was done through normalized gain data. Descriptively, the normalized gain for lateral mathematical thinking can be seen in Figure 1:

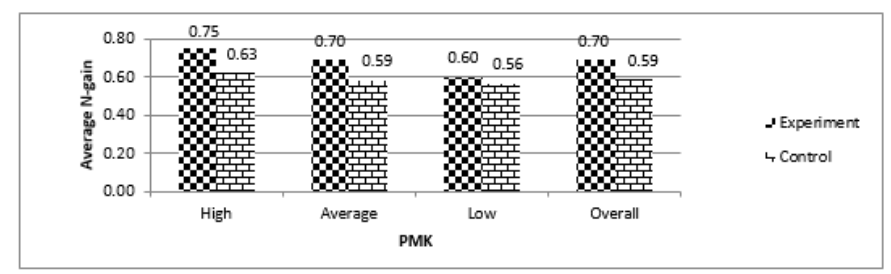

Fig. 1. Mean value of $\langle\mathrm{g}\rangle$ Lateral thinking ability of experimental group and control group.

Comprehensively, the mean $\langle\mathrm{g}\rangle$ experimental group as a whole of 0.70 belongs to the clever category, higher than $\langle\mathrm{g}\rangle$ the control group of 0.59 in the moderate category. Based on $\mathrm{BMK}$, it was identified that the experimental group had a mean of $\langle\mathrm{g}\rangle$ sequentially: BMK (clever, moderate, low) of $(0.75,0.70,0.60)$, BMK clever and moderate were in clever category while BMK Low was in the Moderate category, higher than the control group with a mean of $\langle\mathrm{g}\rangle(0.63 ; 0.59$; $0.56)$ belong in moderate category. The increasing differences indicate that challenge-based learning provides a better contribution of expository learning in order to improve students' lateral mathematical thinking skills. Lateral thinking skills depend not only on the talents of the students through the ability of basic mathematical knowledge, but are greatly influenced by the challenging issues that create opportunities and encouragement for the students to grow [4]. 
Difference test of pretest is on experimental group and control group. Decision criteria is if the value of sig (1-tailed) $0.179>\alpha$ is 0.05 , then $H_{0}$ accepted, it means there is no difference in the pretext of lateral mathematical thinking skill of students, experimental group and control group. This test indicates that before the material was taught, the students' early ability of lateral mathematical thinking in experimental group and control group statiscally did not different in significant.

The difference of increasing in the ability of the two groups through the difference test $\langle\mathrm{g}\rangle$ of lateral thinking experimental group and the Sig (1-tailed) value control group by 0.000 is less than 0.05 , it means $H_{0}$ rejected, therefore the decision is that the improvement of lateral mathematical thinking ability of the students who follow the challengebased learning is higher than students who follow expository learning.

The difference test of lateral mathematical thinking ability based on BMK at clever, moderate, and low level in sequence has Sig value $(0.001,0.000$, and 0.032$)$ smaller than 0.05 , hence Ho is rejected, it means that the improvement of lateral thinking ability of students of experimental group is higher than control group students. This increased distinction indicates that challenge-based learning contributes better than expository learning, in improving lateral mathematical thinking abilities reviewed under BMK at clever, moderate, and low levels. These results show that the similarities between all categories of basic mathematical knowledge of student groups in challenge-based learning have successfully obtained the benefit from conflict to increase its competence, challenge-based learning can broaden knowledge and enrich students' involvement in accomplishing challenging tasks through the variety of ill-structure problem solving [17]. The elaboration of challenges occurs in cooperative learning results in the increase of competence of group members [2, 18].

BMK Interaction Test has a significant effect on lateral mathematical thinking ability with Sig .value (0.000) is smaller than 0.05. For interaction test, based on BMK level and type of learning on mathematical lateral thinking ability, it is seen that the value of Sig. (0.007) is smaller than 0.05, hence it is inferred to reject Ho. This means that there is an interaction effect between learning with BMK (clever, moderate, low), which affects students' lateral mathematical thinking ability. Conflict problems give challenges so as to have a good effect on students in problem solving [19].

Character analysis examines the character of a student comprehensively as measured by a character questionnaire. The components of the analyzed mathematical characters are conceptual and attitudes that are translated into several indicators. The number of item statements as many as 25 items in which measure the positive and negative mathematical characters of students. Individual characters with meticulous indicators; is accuracy in solving math problems. Creative indicator is solving math problems in a creative way. Resilient indicator is feeling challenged by a given math problem. Curiosity indicator is the math function in everyday life and gets answers to problems from various sources.
The average test of mathematical pre-character of the experimental group and the control group is relatively no different, that is 93.00 and 89.76. These results indicate that the experimental and control group mathematical character before applying learning model, it has no significant difference. It is also seen that students in the experimental group have diverse characters. With standard deviations on the pre and post of individual student characters (4.36 and 2.82), the control group was higher than the experimental group, both pre and post. Similarly, the maximum experimental and control gain (117.61 and 102.85) of the experimental group was higher than the control group. Therefore, there is an increase between the mathematical characters of students who receive challenge-based learning, higher than students who gain expository learning.

In order to increase the mean value of $\langle\mathrm{g}\rangle$ based on the indicators of individual mathematical characters that are (1) Meticulous (M), (2) Creative (C), (3) Resilient (R), (4) Curiosity ( C). The indicators of the character of the mathematical group are (1) Leadership (L), (2) Mutual Respect (MR), (3) Cooperate (C), (4) Caring Attitude (CA). Based on the results of data processing, it is identified that the indicators of mathematical characters have increased. Figure 2 presents an average increase of $\langle\mathrm{g}\rangle$ of each indicator in both experimental and control groups. KI: Ex: 75, 65, 70, 68, Control: 45, 35, 39, 40. While Ex: 65, 72, 75, 70 Control: 38, $40,35,35$.

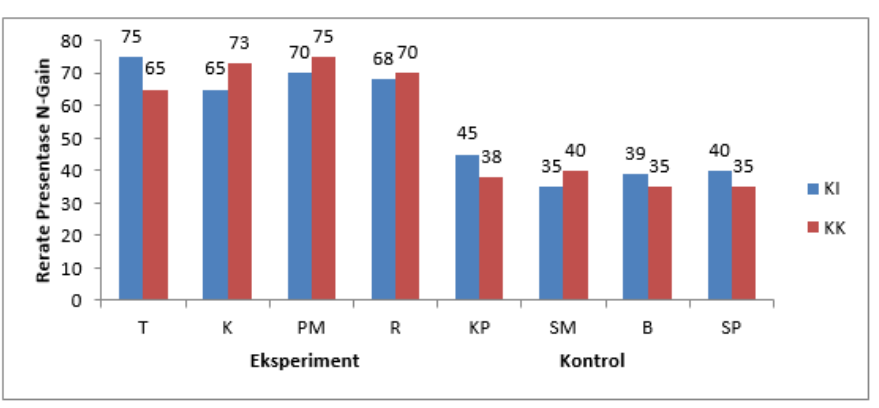

Fig. 2. Average Percentage $<\mathrm{g}>$ Individual and Group Characters

Referring to Figure2, it shows that the increase of students' mathematical character indicators of experimental group is higher than control group. Indicators $\mathrm{KI}$ : M, C, R, C and indicators KK: L, MR, C, CA. Experimental group increase in moderate category, by mean $\langle\mathrm{g}\rangle$ sequencelly $(0,75 ; 0,65$; $0,70 ; 0,68 ; 0,65 ; 0,72 ; 0,75 ; 0,70)$ is higher than control group with mean $\langle\mathrm{g}\rangle$ of $(45,35,39,40,38,40,35,35)$, belongs to low category.

There are differences of student character of experimental and control group with sig. (1-tailed) $=0.000$ is less than 0.05 then $\mathrm{Ho}$ is rejected, it means that the improvement of the character of the students who get CBL learning is higher than the student whose learning in ETS.

Based on the character analysis of the students, the experimental group obtained a higher increase in sufficient category than in the control group. This difference of increase indicates that the group of students who received challengebased learning has a higher character than the group of 
students using expository learning. Overall, improvement of individual character indicators and groups owned by students need to be developed more optimally.

Challenge-based learning is an interesting learning, multidisciplinary learning that contributes positively towards the improvement of students character with full confidence in character-based challenges during the process of transforming key ideas that require confidence when exploring, collaborating, conveying their ideas through presentation in completing tasks, identifying and solving challenging problems, making a difference in their communities, and sharing the best deal results, utilizing the technology they use to solve complex contextual problems $[17,20]$.

Character building involves collaboration of interaction between individual and group that the character of every individual can be formed through interaction process, the individual will not understand without understanding how he interacts with his fellow group, teachers and support community. Students who have a positive character impact on improving lateral mathematical thinking skills. The character of the learner can improve the problem-solving abilities of unfamiliar non-routine mathematical tasks [21, 22]. Character builds a multi dimensional phenomenon that positively affects the success of improving academic achievement of the students [23-26].

The flexibility of the characters is not genetic from birth, but it is formed through the practice of collaborative skill in interaction that grows and develops in accordance with the maturity of students in improving academic ability. Student perceptions of the character and style of learning in the course are manifested through interaction with the academic cultural environment [27]. This interaction has three dimensions: (a) micro-interaction between two individuals; (b) meso interactions between campus environments; and (c) the interaction between the individual environment and the external environment. Institutional characteristics have been shown to positively affect the level of character, persistence, perseverance and graduation of students [27, 28].

According to the findings in this study, the student of preserving teacher education who has lateral thinking skills and character will lead himself to become a professional teacher who is able to penetrate the challenges in his life as a new innovation opportunity that brings better life changes in the future. Challenge-based learning develops knowledge through tasks, even in the modern condition, preparing future professional mathematics teachers not just relying on selfgenerated knowledge, the involvement of teachers and other students to reconstruct the concept of learning materials to resolve conflicts, and the practice of completing continuous tasks is urgently needed to meet the challenges of the problem. The education system is always changing as needed in the community which involves the development of student potential [29].

\section{CONCLUSION}

- The improvement of overall mathematical lateral thinking abilities of students who received challengebased learning were in clever category qualifications, higher than those with expository learning in moderate categories.

- According to the basic mathematical knowledge (BMK) at clever, moderate and low levels, the improvement of lateral mathematical thinking ability of students who receive challenge-based learning is higher than that of students who gain expository learning.

- There is an interaction effect between (challenge-based learning and expository), and BMK level (clever, moderate, low) towards the lateral mathematical thinking ability of students.

- The improvement of individual character and group of students during the challenge-based mathematics learning is higher in experiencing the improvement beginning to develop than the exspository learning.

\section{RECOMMENDATION}

Challenge-based learning should not be used continuously, there are concerns of surfeit, however should be combined with other active learning strategies, methods, and techniques.

\section{REFERENCES}

[1] Lappan, Fey, Fitsgerald, Friel and Phillips, "Getting to know connected mathematics. an implementation guide," New Jersey: Prentice Hall. 2002 .

[2] W. Susilawati, D. Suryadi, and J.A. Dahlan, "The improvement of mathematical spatial visualization ability of student through cognitive conflict strategy," International Electronic Journal of Mathematics Education (IEJME-ISSN: 1306-3030). Vol.12 (2), pp. 155-166. 2017.

[3] J.O. Swafford, G.A. Jones, C.A. Thornton, " Increased knowledge in geometry and instructional practice," Reston: NCTM. Journal for Research in Mathematics Education, 28 (4), pp. 467-483. 1997.

[4] W. Susilawati, "Pengaruh pembelajaran berbasis tantangan dengan strategi konflik kognitif terhadap kemampuan visualisasi spasial, berpikir lateral, dan kegigihan matematis mahasiswa," Disertasi UPI Bandung, 2017.

[5] C.M. Diezmann, "Challenging mathematically gifted primary students,". Australian Journal of Gifted Education, 14 (1), pp. 50-57. 2005

[6] E. De Bono, "Revolusi berpikir,” Bandung: Kaifa. Dewey, J. 1988. Experience and education. In John Dewey, 13, pp. 1938-1939, ed. J.Boydston. Carbondale, IL: Southern Illinois University Press. 2007.

[7] A. Arsisari, "Penerapan pendektan problem centered leraning untuk meningkatkan kemampuan berpikir lateral dan persistence (kegigihan) matematis siswa di Smp," Tesis. Sekolah Pascasarjana Universitas Pendidikan Indonesia, Bandung. 2014

[8] W.Y. Hwang, "Multiple representation skills and creativity effecst on mathematical problem solving using a multimedia whiteboard system," Educational Technology \& Society Journal, 10 (2), pp. 191-212, 2007.

[9] M.A. Ayelea, "Mathematics teachers' perceptions on enhancing students' creativity in mathematics" (IEJME -International Electronic Journal of Mathematics Education, 2016), 11(10), pp. 3521-3536, 2016.

[10] A. Shriki, "Towards promoting creativity in mathematics of pre-service teachers: The case of creating a definition," In R. Leikin (Ed.), Proceedings of the 5th International Conference on Creativity in Mathematics and the Education of Gifted Students. Haifa. pp. 201- 210. 2008 .

[11] P. Sloane, How to be briliant thinker. Latih pikiran anda dan temukan solusi-solusi kreatif. Jakarta: Gramedia, 2011. 
[12] A.I. Maron, "Priorities of teaching mathematics in universities," IEJME-International Electronic Journal of Mathematics Education, 11 (9), pp. 3339-3350, 2016.

[13] Prayitno and A. Khaidir, Pendidikan karakter: Nilai inti bagi upaya pembinaan kepribadian bangsa, Bandung: Widya Aksara Press. 2011.

[14] G. Dwirahayu, "Pengaruh strategi pembelajaran eksploratif terhadap peningkatan kemampuan visualisasi, pemahaman konsep geometri, dan karakter siswa," Disertasi UPI Bandung. 2012.

[15] A.R. Shaidullina, N.Y. Evsyukova, V.A. Mikhailov, F.S. Gazizova, A.R. Masalimova, E.R. Khairullina, and I.I. Galimzyanova, "The Curriculum Project on Professional and Pedagogical Teachers' Communication Culture Formation," Mediterranean Journal of Social Sciences, Vol. 6 (2 S3), pp. 202-208, 2015.

[16] G. Lee, J. Kwon, S.S. Park, J. Kim, H. Kwon and H. Park, "Developmentof an instrument for measuring cognitive conflik in secondary-levelscience classes," Journal of Research in Science Teaching, 40 (6), pp. 585-603, 2003.

[17] W. Susilawati, "The influence of challenge-based learning to the improvement of students' spatial visualization ability," Proceedings International Conference on Mathematics and Science Education. Pp. 144, UPI Bandung, 2017.

[18] P. Sloane, How to be briliant thinker, Latih pikiran anda dan temukan solusi-solusi kreatif, Jakarta: Gramedia, 2011.

[19] A.R. Masalimova, and L.L. Sabirova, "Multi-dimentional classification of types and forms of corporate education," American Journal of Applied Sciences, 11 (7), pp. 1054-1058. 2014.

[20] W.S. Grolnick, and R.M. Ryan, "Autonomy in children's learning: An experimental andindividual difference investigation," Journal of Personality and Social Psychology, 52 (8), pp. 90-98. 1987.

[21] L.L. Castillo, C. Conoley, C. Choi-Pearson, D. Archuleta, M. Phoummarath, and A. Van Landingham, "University environment as a mediator of Latino ethnic identity and persistence attitudes," Journal of Counseling Psychology, 53 (2), pp. 267-271. 2006.

[22] L. Humphries, The mathematics of persistence, thinking applied.com smithsonian institution, 2003.

[23] W.C. Kemp, "Persistence of adult learners in distance education," The American Journal of Distance Education, 16 (2), pp. 65-81. 2002.

[24] A. Parker, "Identifying predictors of academic persistence in distance education," The United States Distance Learning Association Journal, 17 (1), pp. 55-62, 2005.

[25] N.V. Ivankova, and S.L. Stick, "Collegiality and community-building as a means for sustaining student persistence in the computer-mediated asynchronous learning environment," Online Journal of Distance Learning Administration, 8 (3), Pp. 234-245. 2005.

[26] I.L. Harrell, and B.L. Bower, "Student characteristics that predict persistence in community college online courses," American Journal of Distance Education, 25 (3), pp. 178-191. 2011.

[27] L.L. Castillo, C. Conoley, C. Choi-Pearson, D. Archuleta, M. Phoummarath, and A. Van Landingham, "University environment as a mediator of Latino ethnic identity and persistence attitudes," Journal of Counseling Psychology, 53 (2), pp. 267-271. 2006.

[28] Hu and John," Student persistence in a public higher education system: Understanding racial and ethnic differences.The Journal of Higher Education 72 (3), 265-286. 2001.

[29] A.R. Shaidullina, N.Y. Evsyukova, V.A. Mikhailov, F.S. Gazizova, A.R. Masalimova, E.R. Khairullina and I. Galimzyanova, "The Curriculum Project on Professional and Pedagogical Teachers' Communication Culture Formation,"Mediterranean Journal of Social Sciences, Vol. 6 (2 S3), pp. 202-208, 2015. 